(RESEARCh ARTICLE)

\title{
Phytochemical studies of Cissus populnea in Benue State, Nigeria
}

\author{
Uleh Mark ${ }^{1, *}$, Vershima Anyam ${ }^{2}$ and Ojogbayi Sanni ${ }^{1}$ \\ ${ }^{1}$ Department of Forest Production and Products, University of Agriculture, Makurdi, Nigeria. \\ ${ }^{2}$ Center for Agrochemical Technology, Department of Chemistry, Federal University of Agriculture Makurdi, Nigeria.
}

Publication history: Received on 21 September 2017; revised on 27 November 2017; accepted on 08 January 2018

https://doi.org/10.30574/gscbps.2018.2.1.0022

\begin{abstract}
Phytochemical studies of Cissus populnea in Benue State Nigeria was carried out to determine the presence of different chemicals in the stem, based on locality. The state was stratified into three zones using the already existing political grouping. From each of the zones samples of plants were collected with a minimum of $100 \mathrm{~m}$ apart. This is to avoid collection from the same siblings. The collected samples were air dried and pounded to paste. The obtained paste was soaked in hexane $(150 \mathrm{ml})$, ethyl acetate $(150 \mathrm{ml})$ and methanol $(150 \mathrm{ml})$ for $48 \mathrm{~h}$ each. The mixtures were agitated every $4 \mathrm{~h}$ and then filtered in glass jars $(1 \mathrm{~L})$ representing the locations for each zone. The filtrates were left open to evaporate to dryness. After that, extracts were transferred into vials. The ethyl acetate extracts were coded for identification and sent for GC-MS analysis. The results obtained confirmed the presence of different chemicals in the stem of the plants and there was variation in the type of chemical obtained based on location.
\end{abstract}

Keywords: Phytochemical; Ethyl acetate; GC-MS; Cissus populnea

\section{Introduction}

Plants serve as medicine for our bodies and materials for drug manufacturing [1]. Apart from essential nutrients, there are non-essential nutrients or chemical compounds that occur naturally in plants. They contribute to the changes in colour, flavour, and smell in plants. In addition, they provide protection and prevention against diseases affecting the human system.

Plant products that are derived from plant parts such as bark, leaves, fruits, seeds and even roots, have been part of phytomedicine. This suggest that almost all parts of plants contains important chemicals. Many phytochemicals have been found, the most important of these chemical compounds of plant are glycosides, carotenoids, steroids, tannins, flavonoids and tepenoides [1]. Some antimicrobial and antibiotic substances like glycosides, flavonoids and saponinis are found in many plants, however, these compounds are not well established due to poor knowledge and practical techniques in extracting them.

So many indigenous medicinal plants are used as spices and food plants [2]. The knowledge of photochemistry is very important in knowing the composition of the chemical constituents present in plants organs because such information will be of value in the synthesizing of complex chemical substances [3-5].The screening of this phytochemicals also helps in the reasons why some plants could be edible and others poisonous, others good for pregnant mothers and others not. As good as photochemistry is to our world today, there are techniques which detect the most inert and volatile compounds in a plant extract, hence gas chromatography mass spectrometry is very important technique of analyzing chemical compounds. The objective of the study is to determine the different kinds of chemicals present in Cissus populnea.

\footnotetext{
${ }^{*}$ Corresponding author

E-mail address: mark_uleh@yahoo.ca
}

Copyright (C) 2018 Author(s) retain the copyright of this article. This article is published under the terms of the Creative Commons Attribution Liscense 4.0. 
Gas Chromatography-Mass Spectrometry (GC-MS) is a hyphenated analytical method that combines the separation properties of gas-liquid chromatography with the detection feature of mass spectrometry to identify different substances within an extract sample. It is a dual detection technique of analyzing extracts which identifies and quantifies accurately. GC is used to separate the volatile and thermally stable substitutes in a sample while MS fragments the extracts to be identified on the basis of its mass. Its combination coined the name GC-MS. A further addition of mass spectrometer in it leads to GC-MS/MS. Better result is obtained when single and triple quadruple modes are used [6-8].

Cissus populnea Guill and Perr is one of the several climbing tropical shrubs that is believed to promote fertility in both male and female, even though the mechanisms are not clear. Extracts from the stem of Cissus populnea is used to improve fertility in men with low sperm count [9].Thickening agents from plants like Cissus polpulnea, Ogbono, Melon and Okro are used as soup thickener in different parts of Nigeria. It has been reported that $C$. populnea can survive in all seasons. When leaves are squeezed, it becomes slimy and gelatinous. These thickening agents contain nutrients beneficial to health. Also, soups are very important as they make our meals more balanced in nutrients. Soup as a liquid food serves as "appetizer" as they are taken few minutes before the main meal [7].

\section{Material and methods}

\subsection{Study area and sample collection}

The stem of Cissus populnea Guills and Perr plant was collected from three local governments (Ukum, Makurdi and Oju Local Government Areas), one local government per senatorial zone in Benue State, Nigeria, in November 2016. From each zone, three samples of Cissus populnea were collected. A space of at least 100 meters apart was ensured to avoid collecting the same siblings.

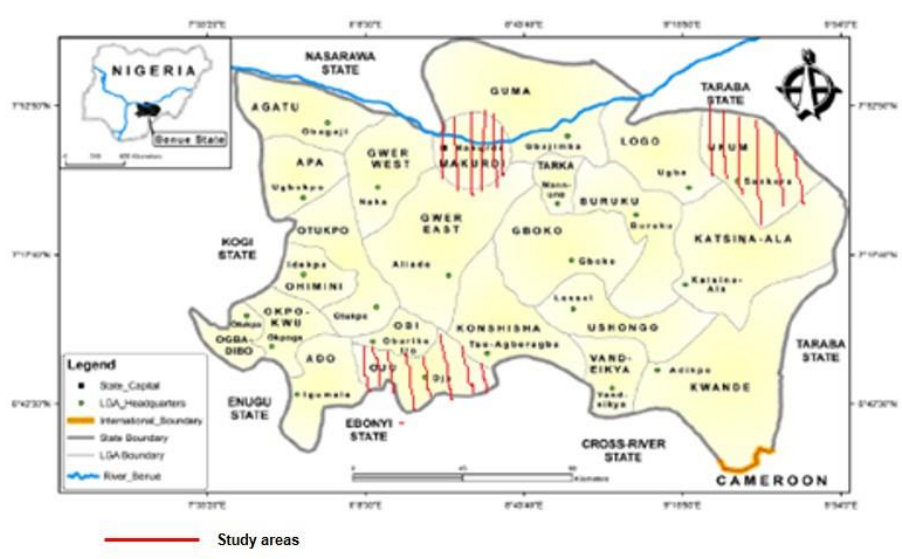

Figure 1Map of Benue State, Nigeria (ministry of lands and survey, Makurdi) (Source: [10])

\subsection{Preparation of samples}

The stem of the $C$. populnea plant was sliced into strands of smaller size and air dried. The dried stem strands were pounded and ground into powder using a local mortar and pestle, after which they were sieved and stored in an air tight container prior to analysis, following the method of [6].

\subsection{Procedure for $n-h e x a n e$, ethyl acetate and methanol extracts}

The powdered plants (10 g) from each of the three locations were macerated in hexane (150 ml), ethyl acetate (150 ml) and methanol $(150 \mathrm{ml})$ for $48 \mathrm{~h}$ each. The mixtures were agitated every 4 hours and then filtered in glass jars (1L) representing the locations for each zone. The filtrates were left open to evaporate to dryness. After that, the extracts were transferred into vials. The ethyl acetate extracts were coded for identification and sent for GC-MS analysis [11].

\subsection{Gas chromatography mass spectrometry analysis}

The GC-system model 7890B and a Mass spectrometric detector model 5977A were used for the analysis. It was set at a temperature of $60{ }^{\circ} \mathrm{C}-325{ }^{\circ} \mathrm{C}: 30 \mathrm{~m} \times 250 \mu \mathrm{m} \times 0.25 \mu \mathrm{m}$ with an initial oven temperature of $60{ }^{\circ} \mathrm{C}$ and a holding time of $3 \mathrm{~min}$. For every ramp rate it was $5^{\circ} \mathrm{C} / \mathrm{min}$ holding time of $0 \mathrm{~min}$ and from $60^{\circ} \mathrm{C}$ to $300{ }^{\circ} \mathrm{C}$ and the total run time was $51 \mathrm{~min}$. The injector temperature was set at $250{ }^{\circ} \mathrm{C}$ (mass analyzer), having a mode split ratio of $20: 1$, split flow of 14 
$\mathrm{ml} / \mathrm{min}$, pressure $4.4867 \mathrm{psi}$ and a total of $17.7 \mathrm{ml} / \mathrm{min}$. The different parameters involved in the operation of Mass spectra were taken at a scan start interval of 50.00; end mass 550.00 and a threshold of 150 [12].

\subsection{Identification of chemical compounds}

The mass spectrum GC-MS was conducted using the database of National Institute of Standards and Technology, which has more than 62,000 patterns. The spectra of the known components stored in the NIST14 Library include the name, area, percentage quality and structures of the chemical compounds of the extracts, which were ascertained by the mass hunter software [13].

\section{Results}

Tables 1, 2 and 3 show the principal chemical compounds present per zone figure 2, 3 and 4 show charts of compounds identified from the GC-MS analysis of Ethyl acetate stem extracts of Cissus populnea from the three senatorial zones of Benue State. Table 4 compares result obtained for all three zones considered for the study. The GC-MS results obtained indicated the peaks, retention time, area, molecular formula and chemical compound quality match of the data base library of National Institute of Standards and Technology.

Table 1 Compounds identified ethyl acetate stem extracts of Cissus populnea collected from Zakibiam, Ukum using GCMS analysis

\begin{tabular}{lllllll}
\hline $\begin{array}{l}\text { Sr. } \\
\text { No }\end{array}$ & Compound name & Peak & $\begin{array}{l}\text { Retention } \\
\text { Time (m) }\end{array}$ & Area (\%) & $\begin{array}{l}\text { Molecular } \\
\text { Formula }\end{array}$ & $\begin{array}{l}\text { Quality } \\
\text { (\%) }\end{array}$ \\
\hline 1 & Hexadecanoic acid methyl ester & 1 & 33.681 & 20.91 & $\mathrm{C}_{17} \mathrm{H}_{34} \mathrm{O}_{2}$ & 98 \\
2 & cis-Octadecanoic acid, methyl ester & 2 & 37.205 & 24.05 & $\mathrm{C}_{19} \mathrm{H}_{36} \mathrm{O}_{2}$ & 99 \\
3 & $\begin{array}{l}\text { Heptadecanoic acid, 16-methyl, methyl } \\
\text { ester }\end{array}$ & 3 & 37.679 & 11.74 & $\mathrm{C}_{19} \mathrm{H}_{38} \mathrm{O}_{2}$ & 97 \\
4 & 1,8 Naphthyridin-2-amine,5,7-dimethyl & 5 & 46.648 & 2.51 & $\mathrm{C}_{10} \mathrm{H}_{11}$ & 25 \\
5 & 6-Octadecanoic acid, (Z)- & & 46.795 & 5.43 & $\mathrm{C}_{18} \mathrm{H}_{34} \mathrm{O}_{2}$ & 44 \\
6 & Nonacos-1-ene & 7 & 50.276 & 2.12 & $\mathrm{C}_{29} \mathrm{H}_{58}$ & 53 \\
\hline
\end{tabular}

Note: Principal chemical compounds deduced from GC-MS.

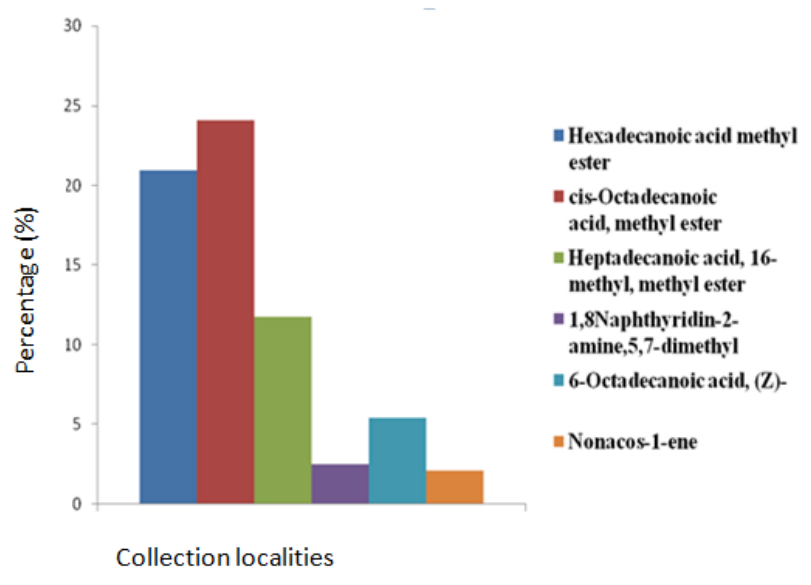

Figure 2 Compounds identified in ethyl acetate stem extracts of Cissus populnea collected from Zakibiam, Ukum 
Table 2 Compounds identified in ethyl acetate stem extracts of Cissus populnea collected from Makurdi (EB1) using GCMS analysis

\begin{tabular}{lllllll}
\hline Sr. No & Compound name & Peak & $\begin{array}{l}\text { Retention } \\
\text { Time (m) }\end{array}$ & Area (\%) & $\begin{array}{l}\text { Molecular } \\
\text { Formula }\end{array}$ & $\begin{array}{l}\text { Quality } \\
\text { (\%) }\end{array}$ \\
\hline 1 & Dodecanoic acid, methyl ester & 1 & 24.414 & 13.94 & $\mathrm{C}_{13} \mathrm{H}_{2} 6 \mathrm{O}_{2}$ & 98 \\
2 & Methyl tetradecanoate & 2 & 29.284 & 6.39 & $\mathrm{C}_{15} \mathrm{H}_{3} 0 \mathrm{O}_{2}$ & 98 \\
3 & Undecanoyl chloride & 3 & 32.940 & 5.44 & $\mathrm{C}_{11} \mathrm{H}_{21} \mathrm{ClO}$ & 43 \\
4 & Hexadeconoic acid, methyl ester & 4 & 33.670 & 7.83 & $\mathrm{C}_{17} \mathrm{H}_{34} \mathrm{O}_{2}$ & 99 \\
5 & 9,12-Octadecanoic acid, methyl ester & 5 & 37.082 & 2.07 & $\mathrm{C}_{19} \mathrm{H}_{34} \mathrm{O}_{2}$ & 97 \\
6 & 9-Octadecanoic acid (z)- methyl ester & 6 & 37.199 & 7.60 & $\mathrm{C}_{19} \mathrm{H}_{36} \mathrm{O}_{2}$ & 99 \\
7 & Methyl stearate & 7 & 37.670 & 3.26 & $\mathrm{C}_{19} \mathrm{H}_{38} \mathrm{O}_{2}$ & 98 \\
8 & 2-Methyl -z,z-3,13-Octadecadienol & 8 & 43.449 & 12.51 & $\mathrm{C}_{19} \mathrm{H}_{36} \mathrm{O}$ & 98 \\
9 & Octadec-9-enoic acid & 10 & 43.706 & 3.52 & $\mathrm{C}_{18} \mathrm{H}_{34} \mathrm{O}_{2}$ & 53 \\
10 & 7- Pentadecyne & 11 & 43.902 & 8.70 & $\mathrm{C}_{15} \mathrm{H}_{28}$ & 96 \\
11 & i-propyl 9-Octadecenoate & 13 & 46.251 & 6.30 & $\mathrm{C}_{21} \mathrm{H}_{4} 0 \mathrm{O}_{2}$ & 22 \\
12 & Carbonic acid, But-3-en-1-yl, pentadecyl ester & 14 & 46.647 & 2.70 & $\mathrm{C}_{10} \mathrm{H}_{18} \mathrm{O}_{3}$ & 35 \\
13 & 6- Octadecenoic acid, (z)- & 15 & 48.184 & 2.18 & $\mathrm{C}_{18} \mathrm{H}_{32} \mathrm{O}_{2}$ & 40 \\
14 & i-Propyl 9-tetradecenoate & 16 & 48.578 & 1.39 & $\mathrm{C}_{17} \mathrm{H}_{34} \mathrm{O}_{2}$ & 44 \\
15 & Benzo(h) quinoline, 2,4-dimethyl- & 7 & 50.663 & 1.23 & $\mathrm{C}_{15} \mathrm{H}_{13} \mathrm{~N}$ & 50 \\
\hline
\end{tabular}

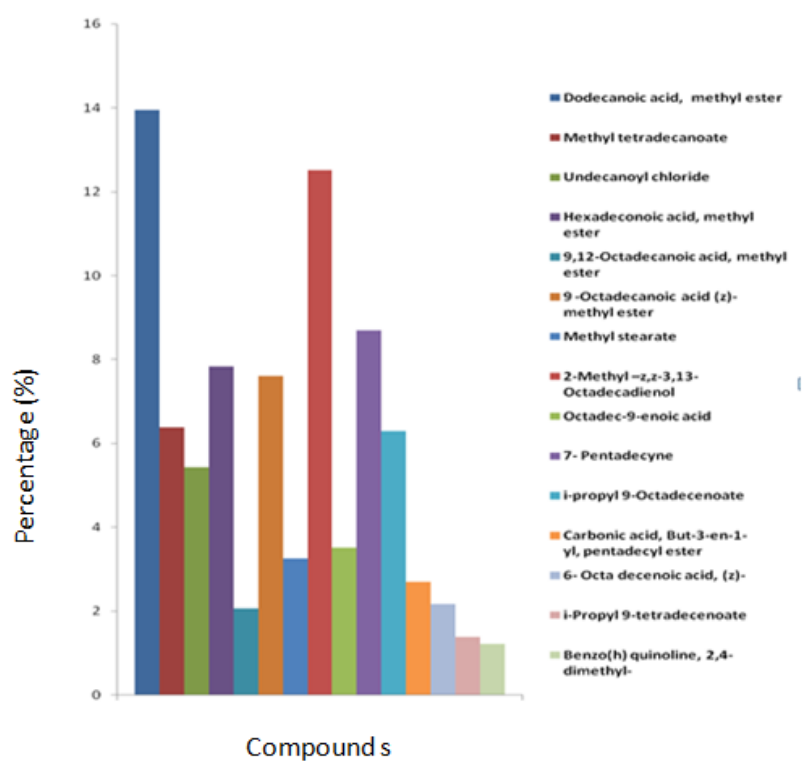

Figure 3 Compounds identified in ethyl acetate stem extracts of Cissus populnea collected from Makurdi 
Table 3 Compounds identified in ethyl acetate stem extracts of Cissus populnea collected from Oju (EC1) using GC-MS analysis

\begin{tabular}{lllllll}
\hline Sr. No & Compound name & Peak & $\begin{array}{l}\text { Retention } \\
\text { Time (m) }\end{array}$ & Area (\%) & $\begin{array}{l}\text { Molecular } \\
\text { Formula }\end{array}$ & $\begin{array}{l}\text { Quality } \\
\text { (\%) }\end{array}$ \\
\hline 1 & Hexadecanoic acid methyl ester & 1 & 33.680 & 18.09 & $\mathrm{C}_{17} \mathrm{H}_{34} \mathrm{O}_{2}$ & 97 \\
2 & 9-Octadecanoic acid (Z)-, methyl ester & 2 & 37.208 & 21.30 & $\mathrm{C}_{19} \mathrm{H}_{36} \mathrm{O}_{2}$ & 99 \\
3 & Methyl stearate & 3 & 37.674 & 9.45 & $\mathrm{C}_{19} \mathrm{H}_{38} \mathrm{O}_{2}$ & 97 \\
4 & n- Hexadecanoic acid & 4 & 47.686 & 6.55 & $\mathrm{C}_{16} \mathrm{H}_{32} \mathrm{O}_{2}$ & 60 \\
\hline
\end{tabular}

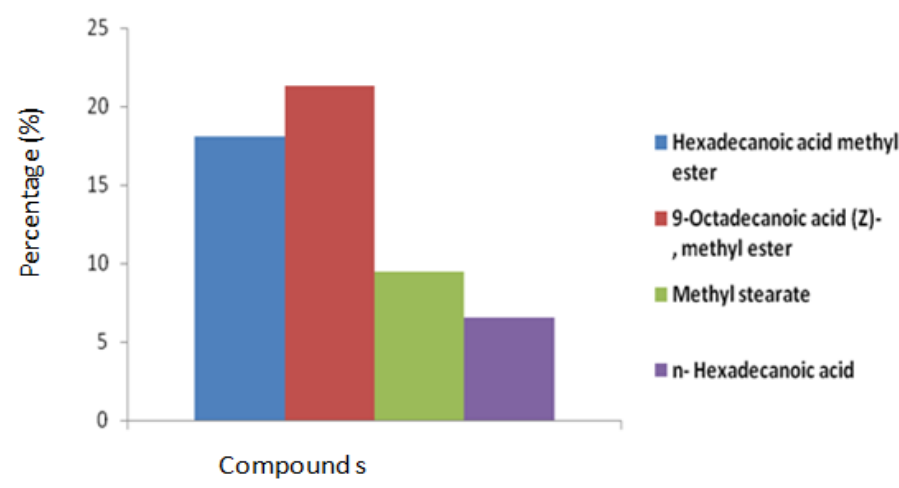

Figure 4 Compounds identified in ethyl acetate stem extracts of Cissus populnea collected from 0ju

Table 4 Comparison of compounds identified in ethyl acetate stem extracts of Cissus populnea in region of Benue State using GC-MS analysis

\begin{tabular}{|c|c|c|c|c|}
\hline \multirow[t]{2}{*}{ Sr. No. } & \multirow[t]{2}{*}{ Compound name } & \multicolumn{3}{|c|}{ Peak area (\%) } \\
\hline & & Zakibiam & Makurdi & Oju \\
\hline 1 & Hexadecanoic acid., methyl ester & 20.19 & 7.83 & 18.09 \\
\hline 2 & Methyl stearate & 11.74 & 3.26 & 9.45 \\
\hline 3 & 6-Octadecanoic acid, (Z)- & 5.43 & 2.18 & 1.42 \\
\hline 4 & Nonacos-1-ene & 15.42 & - & 5.35 \\
\hline 5 & Octadec-9-enoic acid & 5.43 & 3.52 & - \\
\hline 6 & cis-Octadecanoic acid, methyl ester & 24.05 & - & - \\
\hline 7 & Dodecanoic acid methyl ester & - & 13.94 & - \\
\hline 8 & methyl tetradecanoate & - & 6.39 & - \\
\hline 9 & Undecanoyl chloride & - & 5.44 & - \\
\hline 10 & 9,12-Octadecanoic acid, methyl ester & - & 2.07 & - \\
\hline 11 & 9 -Octadecanoic acid (z)- methyl ester & - & 7.60 & - \\
\hline 12 & 2-Methyl-z,z-3,13-Octadecadienol & - & 12.51 & - \\
\hline 13 & Heptadecanoic acid, 16-methyl, methyl ester & 11.74 & - & - \\
\hline 14 & 7- pentadecyne & - & 8.70 & - \\
\hline 15 & i-propyl 9-Octadecenoate & - & 6.30 & - \\
\hline 16 & Carbonic acid, But-3-en-1-yl, pentadecyl ester & - & 2.70 & - \\
\hline 17 & Benzo(h) quinoline, 2,4-dimethyl- & & 1.23 & - \\
\hline
\end{tabular}




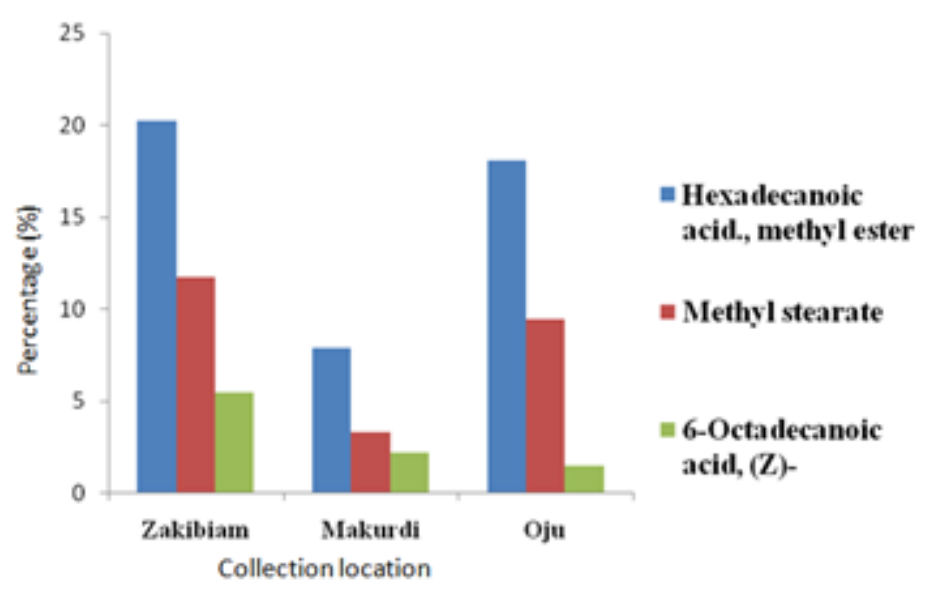

Figure 5 Three abundant chemical compounds present in the ethyl acetate stem extracts of Cissus populnea in Benue State

\section{Discussion}

A total of 17 chemical compounds were identified from the stem of $C$. populnea collected from the different localities in Benue State. This shows how abundant the chemical compounds are, in the stem of the plant. This finding agrees with the results of Onojah et al (14) on the abundance of chemical contents in the fresh stem exudates and the dried pulp of the root of $C$. populnea. Since there is no marked geographical difference in the zones it could be inferred that the variation in the chemical present could be due to soil type. Some of the chemicals found in the three zones, hexadecanoic acid., methyl ester, methyl stearate, 6-Octadecanoic acid, (Z)-, nonacos-1-ene, octadec-9-enoic acid, can serve as a product in perfumes, and cosmetics in industries, medicine for pregnant mothers and infertility problems, spices and protein for proper growth and body maintenance. Some of the chemicals obtained agree with the findings of [15]. In their studies Methyl stearate was observed as a major component occurring in Cissus populnea.

\section{Conclusion}

The result obtained from this study revealed that Cissus populnea is edible as the compounds found in them are not known to be harmful to man. In all the zones, haxdecanoic acid, methyl stearate and octandecanoic acid were found to be common and present in all the samples collected for the zones. However, hexandecanoic acid is abundant in Zakibiam, Ukum and Oju but very scanty in Makurdi. This calls for chemotaxonomic studies of the plants to confirm their taxonomic status as there could be subspecies or varieties among them.

\section{Compliance with ethical standards}

\section{Acknowledgments}

The authors express their sincere gratitude to the Department of Forest Production and Products and the Department of Chemistry, University of Agriculture Makurdi, Nigeria for supporting the research via proper scrutiny.

\section{Disclosure of conflict of interest}

The authors declare that they have no competing interests.

\section{References}

[1] Ajibesin KK. (2011). Dacryodes edulis (G. Don) HJ. Lam: A review on its medicinal, phytochemical and economical properties. Research Journal of Medicinal Plant, 5(1), 32-41.

[2] Akinpelu DA and Onakoya, Z. T. M. (2006). Antimicrobial activities of medicinal plants used in folklore remedies in south-western Nigeria. African Journal of Biotechnology, 7(5), 1078 -1081. 
[3] Mojab F, Kamalinejad M, Ghaderi N and Vanidipour HR. (2003). Phytochemicals screening of some species of Iranian plants. Iranian Journal of Pharmaceutical Research, 2(2), 77-82.

[4] Parekh J and Chanda S. (2007). Antibacterial and phytochemical studies on twelve species of Indian medicinal plants. African Journal of Biomedical Resource, 10, 175-181.

[5] Parekh J and Chanda S. (2008). Phytochemicals screening of some plants from western region of India. Plant Archives, 8, 657-662.

[6] Eleazu CO, Eleazu KC, Awa E and Chukwuma SC. (2012). Comparative study of the phytochemical Composition of the leaves of five Nigerian medicinal plants. Journal of Biotechnology and Pharmaceutical Research, 3(2), 42-46.

[7] Rowley AG. (2001). Evaluating Uncertainty for Laboratories. A Practical Handbook.

[8] Sahil K, Prashant B, Akanksha M, Premjeet S and Devashish R. (2011). GC-MS: Applications. International Journal of Pharmacology and Biological Archives, 2, 1544-1560.

[9] Ojekale AB, Lawal OA, Lasisi AK and Adeleke TI. (2006). Phytochemistry and spermatogenic potentials of aqueous extract of Cissus populnea (Guill and perr) stem bark. Science World, 6, 2140-2146.

[10] Jenke DR. (1996). Chromatographic method validation: a review of current practices and procedures. II Guidelines for primary validation parameters. Journal of Liquid Chromatography and Related Technology, 19(5), 737- 757.

[11] Varsha J, Vaibhav K and Poonam P. (2014). GC-MS analysis of bioactive compounds in methanolic extract of Holigarna grahamii (Wight) Kurz. International Journal of Herbal Medicine, 2(4), 35-39.

[12] Srinivasan K, Sivasubramanian S and Kumaravel S. (2013). Phytochemical profiling and GC-MS study of Adhatoda vasica leaves. International Journal of Pharmacology and Biological Archives, 5(1), 714-720.

[13] Dukes J. (2013). Phytochemical and ethnobotanical databases. www.arsgov/ cgi-bin/duke/.

[14] Onojah PK, Odin EM and Adegbe A. (2015). Comparative analysis of the nutritional contents of the fresh stem exudates and the dried pulp of the root of Cissus populnea plant found in Anyigba, Kogi State, Nigeria. Journal of Science, 4(3), $386-389$.

[15] Moody J0, Ojo 00, Omotade 00, Adeyemo AA, Olumese PE and Ogundipe 00. (2003). Anti-sickling potential of a Nigerian herbal formula (ajawaron HF) and the major plant components (Cissus populnea L. CPK). Phytotherapy Research. 17(10), $1173-1176$.

\section{How to cite this article}

Uleh M, Vershima A and Ojogbayi S. (2018). Phytochemical studies of Cissus populnea in Benue State, Nigeria. GSC Biological and Pharmaceutical Sciences, 2(1), 09-15. 